\title{
CSAE WPS/2004-13
}

\section{Military Expenditure in Post-Conflict Societies}

\author{
Paul Collier and Anke Hoeffler
}

Centre for the Study of African Economies,

Department of Economics, Oxford University

This draft $8^{\text {th }}$ April, 2004

JEL Classification: H56, F35, O10 


\begin{abstract}
Post-conflict situations face a high risk of reversion to conflict. We investigate the effect of military expenditure by the government during the first decade post-conflict on the risk of reversion. We contrast two theories as to the likely effects. In one, military spending deters conflict by reducing the prospects of rebel success. In the other it acts as a signal to the rebels of government intentions. In the signalling model, low military spending signals that the government intends to adhere to the terms of the peace settlement and so reduces the risk of renewed rebellion. We investigate the effects of post-conflict military spending on the risk of conflict, using our existing models of military expenditure and of conflict risk. We find that, consistent with the signalling model, high military spending post-conflict significantly increases the risk of renewed conflict. This effect of military spending is distinctive to post-conflict period, and becomes progressively more pronounced over the decade.
\end{abstract}




\section{Introduction}

During civil war government military spending rises sharply as a share of GDP. In previous work we have modelled military spending and find that on average a civil war raises it by about 1.8 percentage points (Collier and Hoeffler, 2004). This figure of course understates total military spending during conflict since it omits rebel expenditures. With the reversion to peace, the society therefore has the potential for a substantial "peace dividend'. Indeed, taking into account rebel spending, the scope for a peace dividend from reduced military spending is likely usually to be even more substantial once a civil war has ended than after an international war. However, peace after a civil war is often fragile. Using our model of the risk of civil war (Collier et al., 2003), we estimate that during the first five years post-conflict there is a 44 percent risk of reversion to conflict. Any sensible government facing such high risks of civil war would tend to be cautious about rapid reductions in military spending. Further, post-conflict societies inherit at least one powerful military lobby, and quite possibly two if the rebel group is brought into government. Controlling for other characteristics, military dictatorships spend two percentage points of GDP on the military in excess of what fully democratic countries choose to spend, suggesting that where the military is powerful it lobbies for its own interest. Hence, the case for military spending based on prudent deterrence is likely to be reinforced by the atypical power of the military lobby.

Whether for reasons of prudence or due to the power of the military lobby, the typical post-conflict country maintains military spending at a high level - the average postconflict level of military spending is 4.7 percent of GDP. This is only a little less than the 5.2 percent of GDP of military spending during civil war and far above the 3.3 percent spent in peaceful societies. Thus, the government typically foregoes over three-quarters of the potential military expenditure peace dividend that would accrue were it to revert to the pre-conflict level of military expenditure. The issue we explore is whether high military spending is indeed prudent in post-conflict societies. 
The issue is an empirical one because it is possible to construct plausible theories that predict opposing effects. Evidently, the most obvious effect of high military spending is deterrence through reduced prospects of military success for rebel groups. This is reflected in standard military success functions which model the chances of rebel success as a decreasing function of the size of government forces relative to rebel forces (Skaperdas, 1996). However, offsetting this, counter-insurgency to suppress a rebel movement in its early stages is much more difficult militarily than conventional warfare and risks alienating the local population. Incipient rebel groups often attempt to provoke the government military into 'atrocities' that can be used to strengthen recruitment.

In our previous study of military spending we found that the net effect of these opposing influences on the efficacy of military expenditure was for high military spending to exacerbate the risk of civil war. When military spending was instrumented and entered into a conflict risk regression it was found significantly to increase the risk. In that work, however, we did not make allowance for the relatively rare and distinctive circumstances of post-conflict situations. Such situations are distinctive in at least two offsetting respects. On the one hand, as noted, they face radically higher risks of civil war and so may well be in the range in which military deterrence becomes effective. Especially where the civil war has ended in a decisive military victory, the post-conflict government may have learnt how to make high military spending effective. On the other hand, many civil wars end in negotiated settlements, often informal (Doyle and Sambanis, 2003). As Walter (1997) has argued, in contrast to international wars, the parties to a civil war usually lack effective means of binding themselves to respect the terms of such settlements. We argue that this creates a special role for post-conflict military spending as a signal of government intentions. We set out this theory in Section 2. In Section 3 we test the effect of military spending during different phases of post-conflict on the risk of conflict renewal. We find that the effects during the post-conflict phase are distinctive and powerful, and are consistent with a role of military spending as a signal of whether the government plans to adhere to the settlement. Section 4 concludes. 


\section{Military spending as a signal}

Why do post-conflict peace settlements often collapse? If all conditions remained constant presumably the agreement would be maintained. Hence, in accounting for the collapse of a peace agreement, we need to look for changes in circumstances. Yet, the most evident change in circumstances is the economic recovery that commonly occurs post-conflict, and this should tend to reinforce the peace, giving both parties a stronger interest in avoiding disruption by raising its costs.

One likely cause of renewed conflict is if the balance of power changes between the government and the rebels, so that what was mutually advantageous at the time of the settlement comes to be excessively favorable to the weakened party. During the postconflict phase a shift in relative military power is indeed likely. Maintaining a private army is expensive: the viability of a rebel group as an organization depends upon its continued access to finance. Typically, during a conflict, rebel groups use their capacity for violence to raise revenue: a common approach is through extortion rackets or other forms of predation on the high rents earned from natural resource exports. Once a settlement has been reached with the government it becomes much harder to sustain the rebel group as a fighting force. The leadership of a rebellion may well have been accommodated with positions in the government, prestige and income, but lower down the rebel organization fighters are in effect made redundant, usually with some pay-off. As a result, the longer the peace lasts the more the military capability of the rebel organization decays. This decay is much more pronounced than for the government army. After all, the normal state of government armies is to be at peace. They are organized so as to be financed without the need to fight, and to maintain a degree of combat effectiveness through training. By contrast, there is no example in history of a rebel army sustaining itself financially and militarily as a combat-ready force through a prolonged period of peace.

A consequence of this differential erosion of military capability is that rebel bargaining power relative to the government gradually diminishes during the post-conflict period. 
This gives rise to a standard time-consistency problem: the government has an incentive to offer peace terms that, if the rebel group accepts, it is subsequently rational to renege upon. In her study of the difficulties of reaching sustainable peace settlements of civil wars, Walter (1997) concludes that it is the lack of mechanisms for the enforcement of the terms of proposed settlements that is the chief problem. The astute rebel group recognizes the potential for time inconsistent peace offers on the part of the government and so does not accept proffered peace terms, this being one reason why civil wars on average last more than ten times as long as international wars. However, the timeconsistency problem not only prolongs civil war, it contributes to the fragility of peace settlements. If rebels are insufficiently astute they can get caught out by the incentive of the government to over-promise. This need not literally be a matter of 'credulous' rebel leaders being fooled by a 'sly' government. The government leaders of the time may honestly offer terms that they intend to keep, but the next generation of government leaders may not feel bound by these terms, perhaps regarding previous leaders as foolishly generous in not anticipating how circumstances would change. Hence, a rebel group can find itself accepting a settlement that is subsequently modified against its interests.

Perception is important here. As Hirshleifer (2001) has stressed, one cause of conflict is differences in perceptions between the parties: for example, each may be too optimistic about its own military prospects. By the end of a long conflict, perceptions may have been realigned closer to reality. However, if the balance of power shifts during the postconflict phase, the range of mutually advantageous terms changes in favor of the strengthening party and this opens the possibility of new errors in perceptions. The party that is becoming stronger may overestimate the new advantage and unilaterally change the settlement to the point at which the weakened party resumes the conflict. Or, the party that is becoming weaker might fail to appreciate the extent to which its power has eroded, and refuse to accept worsened terms that are still objectively mutually beneficial.

If the military position of a rebel group post-conflict is gradually deteriorating, it needs to anticipate the extent to which this will be exploited by the government. At one extreme 
the government may be keen fully to exploit the potential for changing the settlement to its own advantage. At the other extreme the government might continue to adhere to the settlement despite the change in power. This could arise because the government perceives the costs of reneging upon a settlement as high: for example, it might fear that donors would reduce their aid. Alternatively, it could arise because during the peace the government gradually becomes more averse to war. For example, the composition of the government is likely to change from those with military interests to those with interests in economic and social development.

Because these attitudes of the government are difficult to forecast, at the time of the peace proposal the rebel group does not know whether the proposal is time-inconsistent. The rebel group will use whatever signals of government intentions are available to screen out proposals with low credibility. Those conflicts that reach a settlement imply that at the time of the settlement the rebel group attached some credibility to the government proposal. However, given that the settlement is potentially time-inconsistent due to the erosion of rebel military capabilities, the rebel group will undertake a continuous process of post-settlement screening in order to get early warning of government intentions to renege.

Many aspects of government behaviour post-conflict can potentially be used by the rebel group for screening. For example, the government's rhetoric can be more or less inclusive. However, the level of government military spending is likely to be a powerful signal. If post-conflict government chooses sharply to reduce such spending, using revenues for other purposes, this may reasonably be seen as an irreversible decision. This action would be consistent with a government intention to honour the terms of the settlement, but may not be rational for a government intending to renege on the settlement. Thus, the choice of the level of post-conflict government military spending may well be characterized by a separating equilibrium, with a high level signalling an intention to renege, and a low level signalling an intention to honour the settlement. 
If post-conflict military spending is a revealing signal then high spending might then be associated with a heightened risk of renewed conflict in three ways. First, high spending will be correlated with an intention to renege on the settlement, and reneging is likely to increase the risk of a return to conflict. This association will hold even if the rebel group does not use the level of military spending as a screening device. In this case, high spending would not directly cause a high risk of conflict renewal. Secondly, however, the rebel group might rationally use military spending for screening purposes. High spending would then indicate a government intention to renege on the settlement and the rebel group might then rationally pre-empt this intention before its military power deteriorated further. Third, recognizing that the rebel group would rationally screen by military spending, a peace-loving government might rationally signal its intentions by deliberately reducing military spending. In the two latter cases, a reduction in military spending directly causes a reduction in the risk of conflict.

This signaling role of military spending post-conflict may potentially offset the deterrent effect. In the next section we investigate it empirically. In order to get as close as possible to the pure signaling effect, we control for the beneficial effects of reduced military spending on the economy. Evidently, due to these effects high military spending would indirectly tend to increase the risk of conflict. The issue is whether the direct effect deterrence versus signal - reduces or increases the risk of conflict.

We now formalize the above discussion. Consider a two-round game between the government and the rebel organization in a post-conflict setting. In the first round the government adheres to the peace settlement but chooses the level of military spending high $(\mathrm{H})$ or low $(\mathrm{L})$. This sets the level of military spending not only for the first round but also for the second, reflecting constraints on the ability to make high frequency changes in spending. Following the government's decision, the rebel organization decides whether to resume conflict. It chooses to resume conflict with a probability P. If it chooses to resume conflict, the war persists through both periods. Conditional upon the rebel movement having chosen to continue the peace, in the second round the government chooses whether to continue adhering to the settlement (A), or to renege (R). 
The government may have an incentive to renege on the settlement, because the rebel movement is militarily weakened by the act of settlement. Whether it has such an incentive depends upon its preferences which are not directly observable by the rebels. Thus, depending upon these unobservable preferences, the settlement may be timeinconsistent. Following this decision, the rebel movement can again decide whether to continue the peace or to revert to war.

In accordance with standard military success functions (Skaperdas, 1996), we assume that in the event of combat, military prospects are increasing in military spending. If military expenditure is low rather than high we assume that any government incurs the extra costs of $\mathrm{D}$ in the case of war.

The post-conflict government is potentially of two types: it may be indifferent to war or it may be highly averse to war. In comparison with the war-indifferent government the war-averse government faces additional costs of conflict, $\mathrm{C}$.

Thus, the peace can collapse in either period, or it can persist through both periods. The risk of reversion to war in each period, $\mathrm{P}_{\mathrm{ij}}$, is conditional upon whether the government adheres to the settlement or reneges, $(i=A, R)$, and upon the level of military spending, $(j$ $=\mathrm{L}, \mathrm{H})$. Recall that necessarily in the first period the government adheres to the settlement and in the second period it maintains the military spending chosen in the first period. If the government reneges on the settlement it can capture a bonus, B.

First, we assume that if the government reneges on the settlement that this increases the risk of reversion to war conditional upon the level of military spending. There are various reasons why reneging on the settlement might increase the risk of war: the rebels might adopt a tit-for-tat strategy, or as discussed above, one side or other might be making a mistake. Thus:

$$
\begin{aligned}
& \mathrm{P}_{\mathrm{RL}}>\mathrm{P}_{\mathrm{AL}} \\
& \mathrm{P}_{\mathrm{RH}}>\mathrm{P}_{\mathrm{AH}} .
\end{aligned}
$$


Second, we allow military spending to have a deterrence effect, conditional upon the provocation that the government reneges on the settlement. If the government reneges, there will surely be pressures within the rebel movement for a return to fighting, but a sufficiently high level of military spending may intimidate the rebels and so preserve the peace. Thus:

$$
\mathrm{P}_{\mathrm{RL}}>\mathrm{P}_{\mathrm{RH}} \text {. }
$$

Third, we assume that the rebels use the government's choice of military spending as a screening device to infer government intentions, conditional upon it being rational to do so. If the rebels behave in this way, then low military spending will deter the rebels from a return to combat so that:

$$
\mathrm{P}_{\mathrm{AH}}>\mathrm{P}_{\mathrm{AL}}
$$

Our approach now is to determine the conditions under which the level of military spending can indeed support a separating equilibrium so that a rational rebel group would use it as a screening device.

The government thus faces the choices of high or low military spending, and adherence to the settlement or reneging. We now set out the conditions under which a war-averse government will prefer low military spending and continued adherence to the settlement, whereas a war-indifferent government will prefer to renege upon the settlement and therefore will choose high military spending, even though this reveals its type.

We first consider the pay-offs to different strategies for the war-indifferent government. By construction, these are straightforward and yield a clear dominant strategy. The baseline strategy, which yields a payoff of zero, is to adopt a high level of military spending but to adhere to the settlement. The strategy option is to adhere to the settlement 
and adopt a low level of military spending. The expected pay-off to the government is negative:

$-2 \cdot P_{A L} \cdot D$

This second strategy is thus dominated by the first.

The third option is to renege upon the peace agreement while maintaining high military spending. This yields the bonus, B, with no offsetting costs. This strategy thus dominates the first strategy.

Finally, the government could renege on the settlement while maintaining low military spending. This would yield the pay-off:

$\mathrm{B}-\mathrm{P}_{\mathrm{AL}} \cdot \mathrm{D}-\mathrm{P}_{\mathrm{RL}} \cdot \mathrm{D}$.

This is strictly less than the third strategy. Hence, the war-indifferent government will adopt high military spending and renege on the settlement as its preferred strategy.

Now consider the pay-offs to same four options for the war-averse government. Unlike the war-indifferent government, no strategy is unambiguously dominant; the best strategy depends upon the degree of aversion to war.

If the government adheres to the settlement and adopts a high-level of military spending, the pay-off is:

$-2 \cdot \mathrm{C} \cdot \mathrm{P}_{\mathrm{AH}} \cdot$

If the government adheres to the settlement but adopts a low level of military spending the pay-off is: 
The strategy of low military spending dominates iff:

$\mathrm{D} / \mathrm{C}<\left(\mathrm{P}_{\mathrm{AH}}+\mathrm{P}_{\mathrm{AL}}\right) / \mathrm{P}_{\mathrm{AL}}$

The RHS is the effectiveness of low military expenditure as a signal. As the government is made more averse to war - larger values of $\mathrm{C}$ - and as the signal of low military expenditure is made more effective, (8) becomes increasingly likely to hold.

If the government continues to choose low military spending but reneges upon the peace agreement the pay-off is:

$\mathrm{B}-(\mathrm{C}+\mathrm{D}) \cdot \mathrm{P}_{\mathrm{AL}}-(\mathrm{C}+\mathrm{D}) \cdot \mathrm{P}_{\mathrm{RL}}$.

The strategy of low military spending and adherence to the settlement dominates this strategy iff:

$\mathrm{B}<(\mathrm{C}+\mathrm{D}) \cdot\left(\mathrm{P}_{\mathrm{RL}}-\mathrm{P}_{\mathrm{AL}}\right)$

According to (1) the RHS is positive. The likelihood of this condition holding is therefore increasing in the costs of war, $\mathrm{C}$.

Finally, if the government reneges upon the peace agreement and has high military spending the pay-off is:

$\mathrm{B}-\mathrm{C} \cdot \mathrm{P}_{\mathrm{AH}}+\mathrm{C} \cdot \mathrm{P}_{\mathrm{RH}}$

The strategy of low military spending and adherence to the settlement dominates this strategy iff: 
$2 \cdot \mathrm{D} \cdot \mathrm{P}_{\mathrm{AL}}+\mathrm{B}<\mathrm{C} \cdot\left(\mathrm{P}_{\mathrm{AH}}+\mathrm{P}_{\mathrm{RH}}-2 \cdot \mathrm{P}_{\mathrm{AL}}\right)$.

From (2) and (4) the bracketed term on the RHS is strictly positive, so (12) becomes increasingly likely to hold as $\mathrm{C}$ increases.

Hence, if the war-averse government incurs sufficiently high costs from conflict, there is a separating equilibrium in which it chooses low military spending and adheres to the settlement, while the war-indifferent government chooses high military spending and reneges. The level of military spending in this case reveals the type of the government. The war-indifferent government chooses high military spending even if it knows that this will reveal its type. The rebels can therefore use the level of military spending as a screening device, and the war-averse government can therefore choose low military spending as a signal.

Of course, the analysis does not demonstrate that post-conflict military spending is necessarily used for screening and signalling. But it does show that if a war-averse postconflict government is sufficiently averse to renewed war, and a war-indifferent government gets sufficiently large benefits from reversion to conflict, the chosen level of military spending will be a good screening device for rebel organizations to distinguish between the two extremes.

\section{Empirical testing of the effect of military spending post-conflict}

\section{Approach}

Our approach follows that of Collier and Hoeffler (2004). In that paper we also investigated the effect of military spending on conflict risk but without distinguishing between post-conflict and other situations. As in that study, we utilize our model of the risk of civil war (Collier and Hoeffler, 2004a). This predicts the risk during a five-year 
period based on characteristics at the beginning of the period in question. The data are global subject to data constraints, for the period 1960-99, and includes 55 civil wars which in effect have to be assigned by the model across 750 country-periods.

Military spending may also affect the risk of conflict indirectly, via its effects on the economy. Knight et al (1996) find that during peace military spending tends to reduce growth. In turn, we find that growth reduces the risk of conflict both directly and cumulatively, through raising the level of income (Collier and Hoeffler, 2004a). While these two results suggest that this is one route by which military spending increases the risk of conflict, in this paper our focus is only upon the net effect of deterrence and signalling. The test conducted in this Section is consistent with this focus since the growth rate (lagged) and the initial level of income, are both included directly as explanatory variables. Any remaining effect of military expenditure thus controls for the effect upon growth and income.

Military spending is likely to be endogenous to the risk of conflict: where the risk is high, governments tend to increase spending. In our previous work we have indeed found evidence for such an effect: the lagged predicted risk of conflict significantly and substantially increases military spending. Hence, there will be a positive association between military spending and conflict risk even if such spending has no effect on the risk. In our previous paper we deployed a new technique which enables the instrumental variables approach to be used in a probit regression (Keshk, 2003). In the first stage the endogenous variable is regressed on the instruments as well as the exogenous variables, and in the second stage these estimates are used in a probit regression. The coefficient estimates are consistent and the standard errors are corrected.

Were there no problem of endogeneity, the investigation of military spending in postconflict situations would be straightforward. A term interacting a dummy variable for post-conflict status with military spending would simply be added to the regression. However, the use of such an interaction term in the context of a two-stage probit least square (2SPLS) is currently not feasible in IV programs. We therefore implement the IV 
approach manually, each step in turn. For the second stage this produces identical point estimates of the coefficients to those that generated through IV programs, but the standard errors are not corrected. As we show, however, our approach is likely to be a good approximation to the corrected standard errors.

Results

In column 1 of Table 1 we reproduce the core logit regression of the risk of civil war (Collier and Hoeffler, 2004a). For present purposes the most important explanatory variable is 'peace' - the number of months since any previous conflict. This is negative and significant - conflict risk is much higher in the early years of peace. Just prior to a conflict, the typical country that experiences a civil war has an estimated risk of 22 percent in the ensuing five years. In the first five years of post-conflict peace the country's estimated risk of renewed conflict rises to 44 percent. All of the variables are fully discussed in Collier and Hoeffler (2004a) and will only be discussed here as warranted. In order to use a two-stage IV approach we switch from a logit to a probit estimation. In our case the first stage regression assumes normality in the error term (OLS), thus running a probit rather than a logit is the logical choice. In column 2 we reproduce the core regession as a probit: the change in functional form has little effect.

In column 3 we introduce military expenditure. As in Collier and Hoeffler, (2004), we follow the instrumental variables approach, using five instruments for military expenditure. Three dummy variables proxy external threats: current engagement in international war, past engagement in the period since 1945, and finally the Cold War period. A fourth proxy for external threats is the average military spending of neighbouring countries, weighted by their GDP. The fifth instrumental variable measures the extent of democracy. Although democracy is generally not significant in the risk of civil war, it strongly influences the level of military spending: where the military runs the country military spending rises by around two percentage points of GDP. Column 3 reports the two stage IV regression with corrected standard errors (for details of the procedure see Keshk, 2003). So instrumented, military spending is insignificant. 
In column 4 we repeat the regression of column 3 using the procedure which we will subsequently be using to investigate post-conflict effects. The purpose of the column 4 regression is to establish that this procedure produces very similar results to the IV methodology. The only difference between the IV approach and that used in column 4 is that the standard errors are uncorrected. The same first-stage regression has been used to estimate military expenditure, and the results from this regression again inserted into the second-stage regression. As can be seen by comparing the two columns, the standard errors generated by this approach are very close to those of the IV approach. This gives us some reassurance that the estimated standard errors for the subsequent results will not be too inaccurate.

In column 5 we investigate post-conflict effects. We define post-conflict as being the first ten years after the end of a conflict. We include a dummy variable which takes the value of unity if the five-year period under consideration includes years which are post-conflict. The dummy variable is significant and negative. This does not mean that post-conflict societies are at less risk than other societies, since the much higher risk that they face is captured by the variable 'peace'. Rather, it is necessary to include the dummy variable itself in order to be able to interpret the next variable. This, the key variable of interest, is the interaction term between the post-conflict dummy and the military expenditure variable. This term is positive and significant, implying that in post-conflict situations military spending increases the risk of a reversion to conflict. The addition of these two post-conflict terms does not affect either the military expenditure variable or any other variable. This implies that in the post-conflict context military spending is significantly more adverse in its effect upon the risk of civil war than in more normal situations. Recall that the standard errors for this term are uncorrected and so, although they are likely to be close to their true values, there is a need for caution in the interpretation of the result.

In columns 6 and 7 we try to pin down when during the first post-conflict decade this effect is most pronounced. We therefore divide the decade into its two five-year subperiods and create dummies for each period. In column 6 we repeat the analysis using 
only the first five-year sub-period. The signs of the coefficients remain the same as in column 5, but the variables lose statistical significance. Potentially, this is either because of something genuinely different about the first five-years of post-conflict, or because the sample size of pertinent episodes is necessarily approximately half that used when the post-conflict dummy is defined over a period of a decade. In column 7 we repeat the regression with the post-conflict dummy redefined on the second five-year period postconflict. Now the coefficient on military spending is again significant. We do not regard these results as very robust in view of the reduced sample size once the post-conflict period is divided, but if anything, they suggest that the problems induced by high military spending post-conflict become more important with time.

\section{Interpretation}

Our intention has been to test the hypothesis that military spending post-conflict is used by rebel groups to screen government intentions and is used by governments to signal their intentions. Although the above results do not directly substantiate this hypothesis, they are clearly consistent with that interpretation. Any alternative interpretations must accommodate two somewhat surprising findings.

Firstly, the adverse effect of military spending is significantly stronger in post-conflict situations. This eliminates as explanations for our result most of the obvious routes by which military spending might be counter-productive. For example, a common argument is that because counter-insurgency is very difficult, military attempts to suppress rebellion tend to backfire: the government army commits atrocities against the civilian population and this facilitates rebel recruitment. Such an argument is implausible as an account of why spending in post-conflict situations is differentially counter-productive. Indeed, if anything, we might expect that over the typically long period of a civil war the government military would have acquired differential effectiveness. The signalling

hypothesis accommodates this distinctiveness: both the role of military spending as a signal of government intentions, and the need for an identifiable rebel group to anticipate those intentions are far more likely in post-conflict situations. 
Secondly, the adverse effect of military spending on post-conflict risk becomes increasingly important during the decade. This eliminates as explanations for our result several other potential routes. For example, it is plausible to imagine that a military presence in fragile post-conflict situations randomly generates confrontations that trigger renewed conflict. The larger the military presence, the greater the risk of such events. However, as the 'peace' variable finds in our regressions, the overall risks of peace gradually decline during the decade. Were a military presence simply randomly exacerbating these risks, then its effects would be larger during the first five years of peace than during the second. Again, the signalling hypothesis accommodates this effect. During the first five years post-conflict, the level of military spending - at least as measured in our data set - is likely to be a less reliable screen of government intentions than during the second. First, an initial phase of high military spending may be necessary to cover the one-off costs of demobilization of combatants (Colletta, Kostner and Wiederhofer, 1996). Evidently, rebels should be able to distinguish between high spending for demobilization and high spending for combat capability, but we cannot: our data are for the level of military spending, not its composition. Secondly, high spending might simply indicate inertia. In most post-conflict societies governments have poor policies and weak institutions across a wide range of issues, and so the failure to change a particular component of government spending in the first few years is not a good guide to intentions. However, if military spending persists in being high over the decade, it will increasingly stand out as an exception to a general pattern of reform: policies are not inert in post-conflict societies. A useful measure of policy and institutional change is the Country Policy and Institutional Assessment of the World Bank, which is an annual rating of countries on a five-point scale. It finds that over the course of the first postconflict decade the CPIA typically improves from 2.14 to 3.00. This is a very substantial change, approximately equivalent to the difference between the average sub-Saharan African country and the average South-Asian country. Hence, the signal value of continued high spending increases over time. 


\section{A simulation}

How powerful is the signal transmitted by the military spending decision? To simulate this we take the characteristics of the mean post-conflict country during the post-conflict decade: the period during which low military spending appears to be effective as a signal. At the beginning of the decade the average risk of conflict is 44 percent. Recall that for the typical post-conflict country military spending is only reduced by one-quarter of the increase in spending that occurred during the conflict. Specifically, average post-conflict spending is 4.7 percent whereas average peace spending was 3.3 percent and spending during conflict was 5.2 percent. Now consider the risks generated by the high-spending and low-spending strategies (see Table 2). We represent the 'high-spending' strategy by the decision not to reduce spending at all from the level prevailing during the conflict. Thus, the high-spending strategy involves an addition 0.5 percent military spending relative to the mean post-conflict country. Applying the coefficient on military spending found in Table 1, column 5, this would raise the risk of conflict from 44 percent to 47 percent. We contrast this with a 'low-spending' strategy in which the government reduces spending to the level of the average peaceful country. By the same procedure this reduces military spending by 1.4 percent relative to the mean post-conflict country, and hence reduces the risk to 38 percent. Thus, comparing the two signals, the high-spending strategy raises the risk of reversion to conflict by around 25 percent relative to the lowspending strategy.

\section{Conclusion}

In this paper we have investigated the effect of government military spending on conflict risk in post-conflict situations. During a civil war government military spending is naturally high - typically around 5.2 percent of GDP, as opposed to 3.3 percent in societies with otherwise similar characteristics but a history of internal peace. The restoration of peace thus represents an opportunity for a peace dividend. However, in practice governments tend not to take most of this dividend. In post-conflict situations the risk of renewed conflict is disturbingly high - much higher than in countries with similar 
characteristics but a history of peace. Governments tend to respond to a high risk of civil war with a high level of military spending and post-conflict governments follow this pattern, presumably maintaining spending at high levels in an attempt to deter renewed conflict.

We have found that such a strategy is worse than ineffective. Far from deterring conflict, high post-conflict military spending actually significantly increases the risk of renewed conflict. This result controls for the endogeneity of military spending to conflict risk and so cannot be accounted for as a spurious result of reverse causality. Further, this adverse effect of military spending is distinctive to post-conflict societies.

Since we control for the level and growth of per capita income, the adverseeffect of post conflict military spending cannot be due to its adverse effects on the economy. Though such effects indeed exist, they are additional to the effect that we have identified. We suggest that a possible mechanism by which military spending might be having these peculiar and distinctive effects in post-conflict situations is because of its role as a signal of government intentions. Specifically, military spending may be characterized by a separating equilibrium in which low spending signals a government intention to adhere to the terms of the settlement, while high spending signals an intention to take advantage of the absolute deterioration in rebel military capabilities that occurs while the peace is maintained.

Our results are of both practical and analytic interest. At the practical level they suggest that post-conflict governments might well be misguided if they perceive high military spending as an effective deterrent. Our results in fact underestimate the contribution of reduced military spending to peace. Other research has established that high military spending reduces growth, while growth tends to reduce the risk of conflict. Thus, the overall effect of taking a peace dividend by sharply reducing military spending is partly the direct effect on risk estimated in this paper, and partly the indirect effect via the beneficial effects on the economy. 
At the analytic level, our interpretation of our results, emphasizing the time consistency problems that may be inherent in the negotiated settlement of a civil war, meshes closely with the work of Walter (1997) on the difficulties of concluding a settlement. She argues that the critical and distinctive difficulty in restoring peace during civil wars is the lack of credible commitment technologies: neither party can trust the terms of a proposed settlement even though it might be mutually advantageous. This in turn has practical implications for post-conflict situations. To the extent that the key problem is that the government lacks credible incentives to adhere to a settlement, the international donor community may be able to provide a solution. On standard grounds of poverty reduction there is a good case for substantial aid inflows during the first post-conflict decade (Collier and Hoeffler, 2004b). These aid inflows have the potential to serve a double purpose if 'peace conditionality' is incorporated. As suggested by Boyce (2002), aid conditionality could be used to reinforce adherence to the terms of a settlement. 
Table 1: The Impact of Military Expenditure on the Risk of Civil in Post-Conflict Countries

\begin{tabular}{|c|c|c|c|c|c|c|c|}
\hline & (1) & (2) & (3) & (4) & (5) & (6) & (7) \\
\hline $\begin{array}{l}\text { Estimation } \\
\text { Method }\end{array}$ & Logit & Probit & $\begin{array}{l}\text { Probit } \\
\text { (2SPLS) }\end{array}$ & $\begin{array}{l}\text { Probit } \\
\text { (2SPLS) }\end{array}$ & $\begin{array}{l}\text { Probit } \\
\text { (2SPLS) }\end{array}$ & $\begin{array}{l}\text { Probit } \\
\text { (2SPLS) }\end{array}$ & $\begin{array}{l}\text { Probit } \\
\text { (2SPLS) }\end{array}$ \\
\hline $\begin{array}{l}\text { ln GDP per } \\
\text { capita }\end{array}$ & $\begin{array}{l}-0.950 \\
(0.245)^{* * * *}\end{array}$ & $\begin{array}{l}-0.460 \\
(0.124)^{* * *}\end{array}$ & $\begin{array}{l}-0.607 \\
(0.149)^{* * *}\end{array}$ & $\begin{array}{l}-0.607 \\
(0.149) * * *\end{array}$ & $\begin{array}{l}-0.619 \\
(0.153) * * *\end{array}$ & $\begin{array}{l}-0.610 \\
(0.150) * * *\end{array}$ & $\begin{array}{l}-0.620 \\
(0.151)^{* * *}\end{array}$ \\
\hline$(\text { GDP growth })_{t-1}$ & $\begin{array}{l}-0.098 \\
(0.041)^{* *}\end{array}$ & $\begin{array}{l}-0.051 \\
(0.022)^{* *}\end{array}$ & $\begin{array}{l}-0.026 \\
(0.026)\end{array}$ & $\begin{array}{l}-0.026 \\
(0.026)\end{array}$ & $\begin{array}{l}-0.027 \\
(0.027)\end{array}$ & $\begin{array}{l}-0.030 \\
(0.027)\end{array}$ & $\begin{array}{l}-0.020 \\
(0.026)\end{array}$ \\
\hline $\begin{array}{l}\text { Primary comm. } \\
\text { exports/GDP }\end{array}$ & $\begin{array}{l}16.773 \\
(5.206)^{* * *}\end{array}$ & $\begin{array}{l}7.407 \\
(2.456)^{* * *}\end{array}$ & $\begin{array}{l}10.325 \\
(3.227)^{* * *}\end{array}$ & $\begin{array}{l}10.325 \\
(3.154)^{* * *}\end{array}$ & $\begin{array}{l}10.179 \\
(3.205)^{* * *}\end{array}$ & $\begin{array}{l}10.219 \\
(3.171)^{* * *}\end{array}$ & $\begin{array}{l}10.276 \\
(3.170)^{* * *}\end{array}$ \\
\hline $\begin{array}{l}\text { (Primary comm. } \\
\text { exports/GDP) }\end{array}$ & $\begin{array}{l}-23.800 \\
(10.040)^{* *}\end{array}$ & $\begin{array}{l}-10.160 \\
(4.630)^{* *}\end{array}$ & $\begin{array}{l}-15.904 \\
(6.448)^{* *}\end{array}$ & $\begin{array}{l}-15.904 \\
(6.370)^{* *}\end{array}$ & $\begin{array}{l}-15.655 \\
(6.525)^{* *}\end{array}$ & $\begin{array}{l}-15.787 \\
(6.432)^{* *}\end{array}$ & $\begin{array}{l}-15.582 \\
(6.414)^{* *}\end{array}$ \\
\hline $\begin{array}{l}\text { social } \\
\text { fractionalization }\end{array}$ & $\begin{array}{l}-0.0002 \\
(0.0001)^{* * * *}\end{array}$ & $\begin{array}{l}-0.0001 \\
(0.0001)^{* * *}\end{array}$ & $\begin{array}{l}-0.0001 \\
(0.0001)^{* * *}\end{array}$ & $\begin{array}{l}-0.0001 \\
(0.0001)^{* * * *}\end{array}$ & $\begin{array}{l}-0.0001 \\
(0.0001)^{* * *}\end{array}$ & $\begin{array}{l}-0.0001 \\
(0.0001)^{* * *}\end{array}$ & $\begin{array}{l}-0.0001 \\
(0.0001)^{* * *}\end{array}$ \\
\hline $\begin{array}{l}\text { ethnic } \\
\text { dominance }\end{array}$ & $\begin{array}{l}0.480 \\
(0.328)\end{array}$ & $\begin{array}{l}0.257 \\
(0.168)\end{array}$ & $\begin{array}{l}0.296 \\
(0.194)\end{array}$ & $\begin{array}{l}0.296 \\
(0.191)\end{array}$ & $\begin{array}{l}0.335 \\
(0.194)^{*}\end{array}$ & $\begin{array}{l}0.308 \\
(0.192)\end{array}$ & $\begin{array}{l}0.306 \\
(0.192)\end{array}$ \\
\hline peace & $\begin{array}{l}-0.004 \\
(0.001)^{* * *}\end{array}$ & $\begin{array}{l}-0.002 \\
(0.001)^{* * *}\end{array}$ & $\begin{array}{l}-0.002 \\
(0.001)^{* * *}\end{array}$ & $\begin{array}{l}-0.002 \\
(0.001)^{* * *}\end{array}$ & $\begin{array}{l}-0.003 \\
(0.001)^{* * *}\end{array}$ & $\begin{array}{l}-0.002 \\
(0.001) * * *\end{array}$ & $\begin{array}{l}-0.002 \\
(0.001)^{* * *}\end{array}$ \\
\hline $\begin{array}{l}\text { geographic } \\
\text { concentration }\end{array}$ & $\begin{array}{l}-0.992 \\
(0.909)\end{array}$ & $\begin{array}{l}-0.428 \\
(0.450)\end{array}$ & $\begin{array}{l}-0.937 \\
(0.522)^{*}\end{array}$ & $\begin{array}{l}-0.937 \\
(0.506)^{*}\end{array}$ & $\begin{array}{l}-1.016 \\
(0.519)^{*}\end{array}$ & $\begin{array}{l}-0.961 \\
(0.509)^{*}\end{array}$ & $\begin{array}{l}-0.973 \\
(0.514)^{*}\end{array}$ \\
\hline In population & $\begin{array}{l}0.510 \\
(0.128)^{* * *}\end{array}$ & $\begin{array}{l}0.247 \\
(0.063)^{* * *}\end{array}$ & $\begin{array}{l}0.305 \\
(0.083) * * *\end{array}$ & $\begin{array}{l}0.305 \\
(0.082)^{* * *}\end{array}$ & $\begin{array}{l}0.318 \\
(0.082)^{* * * *}\end{array}$ & $\begin{array}{l}0.306 \\
(0.082)^{* * *}\end{array}$ & $\begin{array}{l}0.315 \\
(0.082)^{* * *}\end{array}$ \\
\hline $\begin{array}{l}\text { military } \\
\text { expenditure }\end{array}$ & & & $\begin{array}{l}0.033 \\
(0.035)\end{array}$ & $\begin{array}{l}0.033 \\
(0.034)\end{array}$ & $\begin{array}{l}0.008 \\
(0.040)\end{array}$ & $\begin{array}{l}0.027 \\
(0.035)\end{array}$ & $\begin{array}{l}0.017 \\
(0.036)\end{array}$ \\
\hline $\begin{array}{l}\text { Postconflict } \\
\text { (1-10 yrs) }\end{array}$ & & & & & $\begin{array}{l}-0.969 \\
(0.436)^{* *}\end{array}$ & & \\
\hline $\begin{array}{l}\text { milex*post- } \\
\text { confl. (1-10 yrs) }\end{array}$ & & & & & $\begin{array}{l}0.121 \\
(0.070)^{*}\end{array}$ & & \\
\hline $\begin{array}{l}\text { Postconflict } \\
\text { (1-5 yrs) }\end{array}$ & & & & & & $\begin{array}{l}-0.522 \\
(0.520)\end{array}$ & \\
\hline $\begin{array}{l}\text { milex*post- } \\
\text { confl.(1-5 yrs) }\end{array}$ & & & & & & $\begin{array}{l}0.068 \\
(0.090)\end{array}$ & \\
\hline $\begin{array}{l}\text { Postconflict } \\
\text { (6-10 yrs) }\end{array}$ & & & & & & & $\begin{array}{l}-0.895 \\
(0.522)^{*}\end{array}$ \\
\hline $\begin{array}{l}\text { milex*post- } \\
\text { confl. (6-10 yrs) }\end{array}$ & & & & & & & $\begin{array}{l}0.146 \\
(0.088)^{*}\end{array}$ \\
\hline pseudo $\mathrm{R}^{2}$ & 0.22 & 0.25 & 0.25 & 0.25 & 0.26 & 0.25 & 0.26 \\
\hline Observations & 750 & 750 & 563 & 563 & 563 & 563 & 563 \\
\hline
\end{tabular}


Table 2: Simulation of risks for high and low military expenditure strategies

\begin{tabular}{l|llllll}
\hline & $(1)$ & $(2)$ & $(3)$ & $(4)$ & $(7)$ & $(8)$ \\
\hline Variable & $\begin{array}{l}\text { Regression } \\
\text { Coefficients }\end{array}$ & $\begin{array}{l}\text { Regression } \\
\text { Coefficients } \\
\text { adjusted }\end{array}$ & mean & $\begin{array}{l}\text { average } \\
\text { Milex }\end{array}$ & $\begin{array}{l}\text { High } \\
\text { Milex }\end{array}$ & $\begin{array}{l}\text { Low } \\
\text { Milex }\end{array}$ \\
Ln GDP per capita & -0.6191 & -0.9906 & 779 & -6.5952 & -6.5952 & -6.5952 \\
(GDP growth)t-1 & -0.0267 & -0.0427 & 1.46 & -0.0624 & -0.0624 & -0.0624 \\
Primary Com.Exports/GDP & 10.1789 & 16.2862 & 0.131 & 2.1335 & 2.1335 & 2.1335 \\
Primary Com.Exports/GDP & -15.6546 & -25.0474 & & -0.4298 & -0.4298 & -0.4298 \\
Ln population & 0.3184 & 0.5094 & 23 million & 8.64 & 8.64 & 8.64 \\
Social Fractionalization & -0.0001 & -0.00016 & 3200 & -0.512 & -0.512 & -0.512 \\
Ethnic Dominance & 0.3354 & 0.53664 & 0.429 & 0.2302 & 0.2302 & 0.2302 \\
Geographic Concentration & -1.0163 & -1.6261 & 0.563 & -0.9155 & -0.9155 & -0.9155 \\
Peace Duration & -0.0028 & -0.0045 & 1 & -0.0045 & -0.0045 & -0.0045 \\
Constant & -1.3269 & -2.1230 & 19.8 & -2.1230 & -2.1230 & -2.1230 \\
Military expenditure & 0.0078 & 0.0125 & 4.7 & 0.0587 & 0.0412 & 0.0649 \\
Milex* post-conflict & 0.1212 & 0.1939 & & 0.9114 & 0.6399 & 1.0084 \\
postconflict1-10 & -0.9692 & -1.5507 & & -1.5507 & -1.5507 & -1.5507 \\
& & & & -0.2238 & -0.5127 & -0.1206 \\
Sum of X·coefficients & & & 44.43 & 37.46 & 46.99 \\
Estimated risk of war & & & & & \\
\hline
\end{tabular}

Simulation Technique used for Table 2:

In Collier and Hoeffler (2004a) we estimate the probability of a war breaking out during a five-year period, and the model can be written in the following general form:

$$
Y_{i t}=a+b X_{i t}+c M_{i, t-1}+d Z_{i}+u_{i t},
$$

where $t$ and $i$ are time and country indicators. We use a logit to estimate the parameters. The dependent variable is a dummy variable indicating whether a war broke out during the five-year period, so that $Y_{i t}$ is the log odds of war. However, in this paper we use a probit to estimate the model and we apply Amemiya's parameter to convert the probit estimates into approximate logit coefficients. Specifically, divide the probit estimates by 0.625 (Amemiya, 1981). The explanatory variables $X_{i t}$ are either measured at the beginning of the period (for example, income per capita, primary commodity exports/gross domestic product [GDP], population), or during the previous five-year period, $\mathrm{M}_{\mathrm{it}-1}$, (for instance, per capita income growth, or are time invariant or changing slowly over time, $Z_{i}$, (for example, social fractionalization). The error term is denoted by $\mathrm{u}_{\mathrm{it}}$.

The expected probability $\hat{p}_{i t}$ of a war breaking out can be calculated by using the estimated coefficients obtained from equation (A1):

$$
\hat{a}+\hat{b} X_{i t}+\hat{c} M_{i, t-1}+\hat{d} Z_{i}=\hat{W}_{i t}
$$




$$
\hat{p}_{i t}=\frac{e^{\hat{W}_{i t}}}{\left(1+e^{\hat{W}_{i t}}\right)} \cdot 100 .
$$

We calculate probabilities for hypothetical observations. For example, we find the average values for $\bar{X}_{i t}, \bar{M}_{i, t-1}, \bar{Z}_{i}$ for post-conflict observations. We then calculate the risk of a conflict breaking out in a postconflict country, $\hat{p}_{i t}$, by applying equation (A3). 
Table 3: Descriptive Statistics

\begin{tabular}{l|lllc}
\hline & \multicolumn{3}{l}{ Sample $(n=563)$} & \multicolumn{2}{l}{ post-conflict $1-10$ yrs $(n=60)$} \\
\hline & mean & Std Dev & mean & Std Dev \\
& & & & \\
War starts & 0.078 & 0.269 & 0.217 & 0.415 \\
GDP per capita (const US\$) & 4246 & 4095 & 1824 & 1513 \\
(GDP growth) $)_{\mathrm{t}-1}$ & 1.704 & 3.458 & 1.161 & 4.969 \\
Primary Comm. Exports/GDP & 0.149 & 0.135 & 0.134 & 0.089 \\
Social Fractionalization & 1744 & 2023 & 2231 & 2317 \\
Ethnic Dominance & 0.425 & 0.498 & 0.433 & 0.500 \\
Peace Duration & 327.7 & 147.739 & 50.55 & 38.53 \\
Population (millions) & 25.7 & 80.2 & 61.7 & 136.8 \\
Geographic Concentration & 0.610 & 0.198 & 0.600 & 0.170 \\
Military Expenditure & 3.355 & 3.312 & 4.037 & 3.387 \\
\hline
\end{tabular}




\section{Data Sources}

Most of the data used in this paper can be downloaded at http://users.ox.ac.uk/ ball0144.

\section{Democracy}

Measures the general openness of the political institutions, it ranges from zero (low) to ten (high). The data source is the Polity III data set as discussed by Jaggers and Gurr (1995).

\section{Ethnic dominance}

Using the ethno-linguistic data from the original data source (Atlas Narodov Mira, 1964) we calculated an indicator of ethnic dominance. This variable takes the value of one if one single ethno-linguistic group makes up 45 to 90 percent of the total population and zero otherwise. We would like to thank Tomila Lankina for the translation of the original data source.

\section{External Threat}

Is a dummy variable which takes a value of one once a country was involved in an international war. Here we consider all international wars after WWII. The main data source is Singer and Small $(1984,1994)$. We updated this data set by using Gleditsch et al (2002), this resulted in the addition of two international wars (Ethiopia - Eritrea, 1998ongoing as of the end of 1999) and India and Pakistan (1999-ongoing as of the end of 1999).

\section{GDP per capita}

We measure income as real PPP adjusted GDP per capita. The primary data set is the Penn World Tables 5.6 (Summers and Heston, 1991). Since the data are only available from 1960-92 we used the growth rates of real PPP adjusted GDP per capita data from the World Bank's World Development Indicators in order to obtain income data for the 1990s.

\section{Geographic Dispersion of the Population}

We constructed a dispersion index of the population on a country by country basis. Based on population data for $400 \mathrm{~km}^{2}$ cells we generated a Gini coefficient of population dispersion for each country. A value of 0 indicates that the population is evenly distributed across the country and a value of 1 indicates that the total population is concentrated in one area. Data is available for 1990 and 1995. For years prior to 1990 we used the 1990 data. We would like to thank Uwe Deichman of the World Bank's Geographic Information System Unit for generating this data. He used the following data sources: Center for International Earth Science Information Network (CIESIN), Columbia University; International Food Policy Research Institute (IFPRI); and World Resources Institute (WRI). 2000. Gridded Population of the World (GPW), Version 2. Palisades, NY: IESIN, Columbia University. Available at http://sedac.ciesin.org/plue/gpw.

\section{International War}


Is a dummy variable which takes a value of one if the country experienced an international war during the period. The main data source is Singer and Small (1984, 1994). We updated this data set by using Gleditsch et al (2002), this resulted in the addition of two international wars (Ethiopia - Eritrea, 1998-ongoing as of the end of 1999) and India and Pakistan (1999-ongoing as of the end of 1999).

\section{Military Expenditure}

Military expenditure is measured as a proportion of GDP, also commonly referred to as the defense burden. Data for 1960-90 was obtained from the Stockholm International Peace Research Institute (SIPRI) and we used data from the Global Development Network for 1991-1999. We measure military expenditure is measured as the average over five year periods, 1960-1964, 1965-69, ..., 1990-95.

http://www.worldbank.org/research/growth/GDNdata.htm

\section{Peace Duration}

This variable measures the length of the peace period (in months) since the end of the previous civil war. For countries which never experienced a civil war we measure the peace period since the end of World War II.

\section{Population}

Population measures the total population, the data source is the World Bank's World Development Indicators 1998.

\section{Primary commodity exports/GDP}

The ratio of primary commodity exports to GDP proxies the abundance of natural resources. The data on primary commodity exports and GDP were obtained from the World Bank. Export and GDP data are measured in current US dollars.

\section{Social, ethnolinguistic and religious fractionalization}

We proxy social fractionalization in a combined measure of ethnic and religious fractionalization. Ethnic fractionalization is measured by the ethno-linguistic fractionalization index. It measures the probability that two randomly drawn individuals from a given country do not speak the same language. Data are only available for 1960 . In the economics literature this measure was first used by Mauro (1995). Using data from Barrett (1982) on religious affiliations we constructed an analogous religious fractionalization index. Following Barro (1997) we aggregated the various religious affiliations into nine categories: Catholic, Protestant, Muslim, Jew, Hindu, Buddhist, Eastern Religions (other than Buddhist), Indigenous Religions and no religious affiliation.

The fractionalization indices range from zero to 100. A value of zero indicates that the society is completely homogenous whereas a value of 100 would characterize a completely heterogeneous society.

We calculated our social fractionalization index as the product of the ethno-linguistic fractionalization and the religious fractionalization index plus the ethno-linguistic or the 
religious fractionalization index, whichever is the greater. By adding either index we avoid classifying a country as homogenous (a value of zero) if the country is ethnically homogenous but religiously divers, or vice versa.

\section{War Start}

We use mainly the data collected by Singer and Small (1994) and Small and Singer (1982). War start is a dummy variable, it takes a value of one if the country was a peace at the beginning of the period and war broke out during following five years, 1960-64, 1965-69 ... 1995-99. If the country remained at peace during the entire period we record a value of zero. A missing value is recorded if the country was at war at the beginning of the period. We record 78 outbreaks of civil war but cannot use all of these observations in our regressions due to missing data for some of the explanatory variables. 


\section{References}

Amemiya, T. 1981. Qualitative Response Model: A Survey. Journal of Economic Literature 19: 481-536.

Barro, R. J. ed. 1997. Determinants of Economic Growth. Cambridge, Massachusetts and London: MIT Press.

Barrett, D. B., ed. 1982. World Christian Encyclopedia. Oxford: Oxford University Press.

Boyce, J.K., 2002. Investing in Peace: Aid and Conditionality after Civil Wars, International Institute for Strategic Studies, Adephi Paper 351, Oxford, Oxford University Press.

Colletta, N.J., M. Kostner and I. Wiederhofer. 1996. Case Studies in War-to-Peace Transition: The Demobilization and Reintegration of Ex-Combatants in Ethiopia, Namibia, and Uganda. World Bank Discussion Paper No 331. The World Bank. Washington D.C.

Collier, P. and A. E. Hoeffler. 2004. Military Expenditure: Threats, Aid and Arms Races, mimeo, Centre for the Study of African Economies, Oxford.

Papers (forthcoming).

2004a. 'Greed and Grievance in Civil War.' Oxford Economic 2004b. 'Aid, Policy and Growth in Post-Conflict Societies', European Economic Review (forthcoming).

Collier, P, L. Elliott, H. Hegre, A. Hoeffler, M. Reynol-Querol, and N. Sambanis, 2003. Breaking the Conflict Trap: Civil War and Development Policy, Oxford University Press, New York, and World Bank.

Doyle, M. W. and N. Sambanis, 2003. 'Alternative Measures and Estimates of Peacebuilding Success', processed, Department of International Relations, Yale, New Haven.

Gleditsch, N.P., Wallensteen, P., Eriksson, M., Sollenberg, M. and H. Strand. 2002. Armed Conflict 1946-2001: A New Dataset. Journal of Peace Research 39: 615-637.

Hirshleifer, J., 2001. The Dark Side of the Force: Economic Foundations of Conflict Theory, Cambridge, Cambridge University Press.

Keshk, O. M. G. 2003. CDSIMEQ: A Program to Implement Two-stage Probit Least Squares. Stata Journal, 3(2), 157-167. 
Knight, M., N. Loayza, and D. Villanueva. 1996. 'The Peace Dividend: Military Spending Cuts and Economic Growth.' IMF Staff Papers 43(1):1-37.

Mauro, P. 1995. 'Corruption and Growth'. The Quarterly Journal of Economics 110:681712.

Small, M. and J.D. Singer. 1982. Resort to Arms: International and Civil War, 18161980. Beverly Hill: Sage.

Singer, J.D. and M. Small. 1994. Correlates of War Project: International and Civil War Data 1816-1992. Inter-University Consortium for Political and Social Research, Ann Arbor, Michigan (data file).

Summers, R., and A. Heston. 1991. The Penn World Table (Mark 5): An Expanded Set of International Comparisons, 1950-1988. The Quarterly Journal of Economics 99:32768.

Skaperdas, S. 1996. 'Contest Success Functions'. Economic Theory 7:283-90.

USSR, 1964. Atlas Narodov Mira, Department of Geodesy and Cartography of the State Geological Committee of the USSR. Moscow.

Walter, B.E.,1997. 'The Critical Barrier to Civil War Settlement', International Organization, 51, 335-65. 